\title{
The Role of Religious Harmony Forum for Maintain Religious Life in Palangka Raya
}

\author{
Prasetiawati \\ Christian Theology Department in State Institute for Christian Studies Palangka Raya \\ \{prasetiawati@ymail.com $\}$
}

\begin{abstract}
This research is to determine the role of Religious Harmony Forum (FKUB) based on regulation of the Minister which was in conducting dialogue with religious organizations and community leaders and efforts to maintain interreligious harmony in Palangka Raya. This research is a case study using a qualitative approach with data collection by interview and observation. Results of this research prove that religious harmony in Palangka Raya is running well and it is based on the fact that in its city almost never happened such as significant religious conflicts. Religious harmony is based on a harmonious relationship by visiting each other in religious activities and social activities. Meanwhile, the role of the Forum for Religious Harmony has carried out its duties and responsibilities properly through the socialization of government regulations and other programs and has served as an extension of the religious community to convey aspirations to the government.
\end{abstract}

Keywords: Role, Religious Harmony Forum, Sustain Religious Life

\section{Introduction}

Indonesia is a country notable for its multicultural society, where people of different ethnic, linguistic, culture, and religious background live together alongside each other. Many of the world's major religions are practiced in Indonesia such as Islam, Christianity, Catholicism, Buddhism, Hinduism and Confucianism. In such multi-religious setting, religious harmony becomes a critical factor in order for development taking place smoothly, and for the implementation of a safe, prosperous and advanced community development. Multi-religious praxis is an activity of all religious communities in working together to improve the quality of life for a pluralistic society [1]. For Indonesia, the diversity of religions can be the country's most powerful treasure and strength, but on the other hand it potentially rise conflict in the absence of good enforcement of noble and tolerance values among the existing religious communities.

Indonesia has Pancasila as its national foundation and philosophy, which is embodied in the motto of Bhineka Tunggal Ika (unity in diversity). This means that the sustainability of community development and the country's development in general can only be achieved if the spirit of unity is properly maintained and nurtured [2]. The most common of the many factors that often cause conflict between religious groups is believed to be rooted from the wrong interpretation of religious doctrine taught in each religion that possibly creates isolationism and confrontationalism views. Isolationist view each religion as a completely independent universe where adherents of particular belief live and grow on their own, while confrontationalists view 
adherents of other religion as threats for their own belief, deserving suspicion and hatred. Violent incidents rising in the name of religion are actually triggered by misinterpretation, misinformation and narrow insight of other religions. Therefore, in this case, the government and community should work together to look into the most appropriate solution to address these conflicts and to build religious harmony for the sake of the nations' unity [3].

Recently, there is a growing interest in studies on various collaboration between religious groups, as shown by initiatives taken by the community to hold meetings or dialogues in forums or seminars as people starts to realize the increasingly challenging situation in which the country is at risk of disintegration. As follows, to direct all the potential for diversity in a positive direction, of course, a serious effort is needed that can foster and even maintain the conditions of a society that prioritizes the values of harmony and an attitude of tolerance among religious believers. Among the forms of harmony is the willingness of all parties to dialogue, because dialogue itself involves the existence of views from one party's positive approach to other parties[4].

FKUB or the forum on religious harmony, hereinafter referred to as FKUB, is one of the governing bodies responsible in maintaining the values of unity and humanity for purpose of the country's social stability. On the foundation of this understanding, this research seeks to learn about the role of FKUB in Palangka Raya as defined by article 9 of the Joint Ministerial Decree of the Ministry of Religion and Ministry of Domestic Affairs (PBM) on 2006 [5] regarding how to establish a dialog forum between religious organization and community figures as part of the efforts to maintain religious harmony in Palangka Raya, as well as to channel the community and religious organizations' aspirations through recommendations that would inform the leaders in Palangka Raya as policy makers who would spearheads the proper dissemination of law, regulation and policies in religious sector that would encourage religious harmony and community empowerment in Palangka Raya. FKUB develops communication strategies that contribute positively to the conflict resolution process. The efforts used are persuasive and dialogic. Apart from its achievements, these communication efforts have not been fully maximized and can guarantee that similar conflicts will not be repeated [6].

Even though it is very plural, the city of Palangka Raya is a conducive area, even so there are still problems that arise, one of which is the problem of harmony which is disturbed when issues related to intolerance between religious communities arise, besides that there are still many things that arise. in society with regard to issues of religious communities. This condition is an event that occurs in society that requires proper handling from all parties and especially the Forum for Religious Harmony (FKUB) in seeking efforts to create religious harmony in order to create a strong Unitary State of the Republic of Indonesia (NKRI). Religious symbols in Indonesian society still reflect the behavior of the people in understanding and practicing their religious teachings. This reflection became the basis of the family in the fostering of religious values. The family plays a huge role in creating an atmosphere of harmony and diversity [7]. Other than that Inter-religious dialogue under the program of FKUB of Indonesia can be as a modal and place as results of Khotimah's research prove that religious harmony and religious awarness where become intrinsic value of universal humanity. Furthermore, every adherent should understand their religion and also aware of religion diversity and differencies [8].

From this background, this research is to determine the role of the Palangka Raya City Religious Harmony Forum (FKUB) based on Article 9 regarding the 2006 Joint Regulation of the Minister of Religion and the Minister of Home Affairs (PBM) in conducting dialogue with religious organizations and community leaders in efforts to maintain inter-religious harmony in the Municipality of Palangka Raya, as well as channel the aspirations of religious mass organizations and the aspirations of the community in the form of recommendations as policy 
materials for regional heads in the Palangka Raya Municipality, then what is the role of the Forum for Religious Harmony in disseminating legislation and policies in in the field of religion related to religious harmony and community empowerment in the Municipality of Palangka Raya.

\section{Theoritical Framework}

\section{a) Religious Harmony Forum (FKUB)}

From this background, this research is to determine the role of the Palangka Raya City Religious Harmony Forum (FKUB) based on Article 9 regarding the 2006 Joint Regulation of the Minister of Religion and the Minister of Home Affairs (PBM) in conducting dialogue with religious organizations and community leaders in efforts to maintain inter-religious harmony in the Municipality of Palangka Raya, as well as channel the aspirations of religious mass organizations and the aspirations of the community in the form of recommendations as policy materials for regional heads in the Palangka Raya Municipality, then what is the role of the Forum for Religious Harmony in disseminating legislation and policies in in the field of religion related to religious harmony and community empowerment in the Municipality of Palangka Raya.

In order to create harmony, it is necessary to identify the causes that make it incompatible. There are non-religious factors that cause disruption in addition to religious factors. The nonreligious factors in question are economic disparities, political interests and differences in sociocultural values. Meanwhile, religious factors that can be the cause of disharmony, even if it is indirect, include religious education, religious broadcasting, religious assistance, marriage between different beliefs [9]

The influence of non-religious and religious factors that cause dissonance between religious communities, so efforts to establish harmony must continue to be fought for and the communication link factor becomes an important element in an effort to reduce disharmony. Through communication that is well established it is possible to overcome the factors that cause dissonance. Secara umum, tugas-tugas FKUB dalam memelihara kerukunan umat beragama di Indonesia is very much supported by many factors, including the culture of a society that respects each other, respects each other and helps to help which has been built since the ancestors of this nation. This is reflected in various kinds of local wisdom that describe this condition. In addition, the plurality of Indonesian people with different beliefs, ethnicities, ethnicities and groups is also a supporting factor for harmony [10]

Communication between religious believers can be mutually well intertwined through increased cooperation between religious believers, for example through cooperation in the social, economic and cultural fields. In the field of culture, cooperation can be carried out, among others, in the form of activating or reviving a culture of peace and local wisdom. As a dignified nation, actually the Indonesian nation is very rich in local wisdom which tends to vary and varies according to each region, but the nuances or the essence are basically all the same because they try to teach and bring into the efforts of a harmonious and peaceful life. And build cooperation between various elements or different religious groups. 


\section{b) Role of Religious Harmony Forum}

Role is always associated with relationship context because only in relationship roles can be identified. Therefore, the role of the person or organization/institution can be recognized from the accordance of its activities with the functions and social status attached. In the govemment's view, the position and role of FKUB are very important in maintaining good relations between the State and religion [11]. The role of the Forum for Religious Harmony (FKUB) in articles 8, 9 and 10 in the joint ministerial decree is described in full in the articles which read as follows:

\section{Article 8}

1) The Forum for Religious Harmony (FKUM) is formed in provinces and districts / cities

2) The establishment of the Forum for Religious Harmony (FKUM) as referred to in paragraph shall be carried out by the community and facilitated by the regional government.

3) The Forum for Religious Harmony (FKUM) as referred to in paragraph (1) has a consultative relationship.

\section{Article 9}

1) The Provincial Religious Harmony Forum (FKUM) as referred to in Article 8 paragraph (1) has the following tasks:

a) Conducting dialogue with religious and community leaders

b) Accommodate the aspirations of religious mass organizations and the aspirations of the community.

c) Channeling the aspirations of religious mass organizations and society in the form of recommendations as material for governor policies, and

d) To disseminate information on laws and policies in the religious sector relating to religious harmony and community empowerment.

e) Provide written recommendations on applications for the establishment of houses of worship.

\section{Article 10}

(1) Membership of the Forum for Religious Harmony (FKUB) consists of local religious leaders.

(2) The maximum number of members of the provincial Forum for Religious Harmony (FKUB) is at most 21 people and the number of members of the Regency/City Religious Harmony Forum (FKUB) is at most 17 people.

(3) The composition of the members of the provincial and regency/municipal Religious Harmony Forum (FKUB) as referred to in paragraph (2) shall be determined based on the ratio of the number of followers of local religions with the representation of at least one person from each religion in the province and district/city.

(4) The Forum for Religious Harmony (FKUB) is chaired by one chairman, 2 deputy chairmen, one secretary, one deputy secretary who are elected by deliberation by the members.

As stated in the joint ministerial regulation regarding the formation of the Forum for Religious Harmony (FKUB), it is stated that the members are local religious leaders, and are formed by the community (article 8). Meanwhile, the term religious leader is defined as a 
community figure of religious communities, both those who lead and those who do not lead religious organizations that are recognized and respected by the local community as role models (article 1 point 5). Thus, the role of the Forum for Religious Harmony (FKUB) in maintaining religious harmony is the task of the community and the government in the development of religious communities. The maintenance of religious harmony is a joint effort between religious communities and the government in the field of service, regulation, and empowerment of religious communities (article 1 point 2). Placement for religious people before government placement means that the role of religious people as an element of society has a bigger responsibility than the government. The community has room for participation to participate in development in the reform era to create a strong civil society.

\section{c) Pluralism in Palangka Raya}

The city of Palangka Raya is inhabited by a vast diversity of people from different tribes, cultures, languages and religions. However, issues regarding intolerance are very rarely found, which indicates that the community has been able to lead their lives peacefully alongside the others despite having differences in culture, ethnicity, language and religion. The following is 2010 statistics shows the population rate in Central Kalimantan based on religion adherence. The data suggests that Central Kalimantan Province is populated by 2,212,089 inhabitants, and the largest populated region is the Regency of East Kotawaringin. Central Kalimantan has 13 Regencies and 1 district.

As for religion, people in Central Kalimantan mostly embrace Kristen, Katolik, Budha, Hindu dan kong Hu Chu. Moslem sits on the top as the majority of religion embraced across all districts and regions except for Gunung Mas whose majority of population practice Christianity. On that note, the next largest Christian population is found in Palangkaraya and Kapuas, while the largest number of Catholic community inhabits Barito Selatan, Barito Timur andBarito Utara. Hinduism is also on big number in Kapuas and Palangkaraya. All data was based on the 2010 report issued by the Indonesian Statistical Department of 13 regency and one municipality in Central Kalimantan.

Particularly, most people embrace Islam, and no Confucianism in the statistic data:

The vast diversity in religious belief in Palangka Raya put the city named as pluralist city, and creating peaceful and harmonious life among the people requires serious measures from the government. Therefore, the Forum for Religious Harmony plays an important role in ensuring the security for the people Palangka Raya to practice their religion.

The second congress Forum for Religious Harmony in Jakarta concerning guidelines for Organization and Working Procedure of the FKUB decided that FKUB is necessary to implement article 3 paragraph (4) and article 11 paragraph (1) Governor Regulation Number 6 of 2010 concerning changes to governor regulation number 6 of 2007 regarding the establishment of the (FKUB) and the Advisory Council of the Provincial and District / City Religious Harmony forums in Central Kalimantan and the results of the members of the Forum for Religious Harmony in Palangka Raya on September 14, 2015 in Palangkaraya. The Mayor of Palangkaraya's Decree on the establishment of the 2015 - 2020 FKUB Secretariat and Secretariat of the Palangka Raya Religious Harmony Forum was formed based on PBM number 9 and 8 of 2006 and Central Kalimantan Governor Regulation number 6 in 2007.

FKUB Membership based on percentage of the existing religious community, and in 
Central Kalimantan, the 17 members consists of 9 Muslims, 4 Protestants, 2 Hindus, 1 Catholic and 1 Buddha. Currently, FKUB has been established in all Districts and Cities in Central Kalimantan (13 Regencies and 1 City). The Provincial FKUB has received the assistance of the Secretariat Building from the Central Kalimantan Provincial Government on the second floor at Jln. Juanda No. 19 Palangka Raya. FKUB is formed at provinces and districts/cities level. The establishment of FKUB was carried out by the community and facilitated by the regional government. FKUB has a consultative function. FKUB is chaired by 1 (one) chairperson, 2 (two) deputy chairmen, 1 (one) secretary, 1 (one) deputy secretary, who is chosen by deliberation by members.

\section{Method}

This research is a qualitative type with a case study approach that aims to find meaning, investigate processes and gain a deep understanding and understanding of various existing conditions and situations that arise from individuals, groups, or situations. The research site of Palangka Raya Municipality and what was studied was the role of the Management of the Forum for Religious Harmony (FKUB) in the city of Palangka Raya. The research subjects in this study were key informants, namely 5 members of the Forum for Religious Harmony (FKUB) in Palangka Raya City, while complementary informants were 5 people representing community leaders and religious leaders as well as the deputy mayor as the FKUB advisory board. Palangka Raya City.

The techniques used to collect data are observation, interviews and documentation. Observations were made to obtain data about the activities carried out by the board of the Forum for Religious Harmony (FKUB) in Palangka Raya City in carrying out their roles in carrying out their duties. In principle, qualitative data analysis is carried out simultaneously with the data collection process. Data analysis techniques were performed using data analysis techniques proposed by Milles and Huberman [12].

\section{Result and Discussion}

\section{a) Role of Religious Harmony Forum}

In 2006, the government of Indonesia issued a national policy on the establishment of a Forum for Religious Harmony (FKUB), but the community has started long before in their efforts to promote the initiative. There had been dialogue between religious figures and joint social activities among the communities, such as building facilities and infrastructure together. The community plays their role to maintain religious harmony in FKUB by proactively accommodate arising complaints and issues through formal and informal dialogues and formulate recommendations based on these aspiration to the government as a resource to inform the higher-level's decision making polices. Another responsibility of FKUB is to help the government conduct a public meeting to discuss legislation and policies related to religious harmony and community empowerment. Meanwhile, the role of the government is to be the facilitator and motivator of the community's efforts. In the implementation, the role of government in this forum means that the government would provide facilities and empower the community by forming an advisory board council consisting of deputy governors, heads 
of offices/regions of the religious department and other government agency representatives. This council mainly work with assisting the regional head in formulating policies on religious harmony, facilitating collaboration between FKUB and the regional government, and facilitating collaboration between government agencies in maintaining religious harmony (PBM article 11). In other words, the task of the FKUB Advisory Council is not limited to an advisory level, but rather at a larger scope, namely to support the implementation of FKUB function and promote the FKUB as the leading sector.

First of all, the strategic role of FKUB can be seen in the decree implementation, and then in the daily duties of FKUB as stated in the decree, PBM Article 9 paragraph (1) and (2), as follows:

a. To conduct dialogue between community and religious leaders.

This task was assigned Palangka Raya FKUB, supported by regional government, and has been implemented by FKUB, especially in the form of official dialogues and official meetings. The official dialogue was conducted by the Palangka Raya FKUB in the presence of FKUB Palangka Raya City Advisory Board consisting the Mayor of Palangka Raya and his deputy, head of the Palangka Raya Ministry of Religion office, Head of Palangka Raya National Unity and Political Agency, Kapolresta Palangka Raya, Chief Palangka Raya City Prosecutor's Office, Chair of the Palangka Raya City District Court and Chair of the Palangka Raya City Religious Court. The dialogue, discussed about possible efforts and collaboration of all relevant parties in maintaining religious harmony in Palangka Raya, but this is hardly implemented considering the difficulty of bringing together all advisory council members together. From the period of 2015 to 2017, only one meeting was held, and not all the invited participants and committee attended. The dialogue was not limited to official meetings only, some of but also in informal visits by FKUB to local religious center, educational and social facilities such as orphanages and others. Other dialogues frequently took place when the Palangka Raya FKUB came to observe on the construction of religious centers. Other informal dialogues took place during FKUB visit to houses asking for recommendations for the establishment of religious centers. During these visits, FKUB recorded the details about the proposed buildings, such as land documents, permits, Building Construction Permits (IMB), letters of approval from surrounding residents, and others that are required for FKUB to provide recommendations on the building construction. Several buildings were visited by FKUB since the 2015, namely the Ar Rabbani at Temanggung Tilung street, Gereja Sidang Jemaat Allah at Yos Sudarso street, Gereja Bethel Indonesia at Yos Sudarso street, gereja Gloria at Kutilang street, Gereja Sidang Jemaat Allah Pancaran Kasih at Bakung Merang street, Some churches at Mahir Mahar, Tinggang XIV, Junjung Buih street, a small mosque at Komplek BPJS, and Mesjid Akhoidah at Tambun Bungai street Palangka Raya. There were more but not all recorded here. In addition to conducting dialogues in meetings and visits to community leaders, FKUB also carried out dialogues through media. Media dialogue was conducted through broadcasting on TVRI Kalteng on July 15, 2015 focusing on with the theme of religious harmony, and at the end of 2015 on the theme harmonization of religious people in Palangka Raya. The task assigned to FKUB in conducting dialogues with religious and community leaders has the total support from the regional government, and generally been well implemented by the FKUB Palangka Raya, especially in form of official dialogues and meetings. In fact, the dialogue was not limited to official meetings; some took place during visits to local religious facilities. Some were individual dialogues between fellow members of the Palangka Raya City FKUB themselves in various opportunities for interaction between themselves and with the community. Unfortunately FKUB did not record the dialogues and thus cannot how much dialogue 
activities are considered adequate, although there is no standard qualitative size. Some interviewers consider long dialogue is good enough to retrieve the information. In terms of its contents, the interview definitely needs a proper plan so as to be delivered effectively and in a cooperative manner.

b. Accommodating the aspiration from the Relious Organizations and the Community. FKUB normally take notes on three point of aspirations, namely about the issue of society harmony, religious harmony and land dispute. The information about society harmony will be channeled by FKUB to the mayor of Palangka to be considered and acted upon. "One of the people's aspirations regarding community harmony was for the government of Palangka Raya to pay attention to the dimly lit street vendor stalls in the outer ring area as many residents reported suspicion of prostitution practices". There is also issues on land dispute, borders and ownership which was conveyed by FKUB to the government. "Land disputes related to establishment religious facilities is the most popular issues heard by FKUB." The task of accommodating the aspirations of community and religious organizations has been carried out by FKUB, but it is difficult to record and evaluate. As the members the FKUB are representatives of religious assemblies, their aspirations are also taken into account and have been accommodated.

c. Channeling the aspiration from the religious organizations and community in form of policy recommendation to inform the policy and decision makers.

The task related to this point that has been implemented by FKUB was on the issues related to the suspicious street vendor along the Adonis Samad ring road as residents reported disturbance and complained. FKUB took the step to report the complaints to the regional government of Palangka Raya for a further follow up. This means that all aspirations conveyed by the community as well as by religious organizations are accepted and can be processed if they meet the applicable legal provisions in the State of Indonesia and regional regulations in Central Kalimantan. Evaluation of this task is not easy, however it is not stuck there as the FKUB is following up at the Regional Deliberation forums and Coordination Meetings to make sure the voices are heard.

d. The role of FKUB Palangka Raya in disseminating regulations and policies for religious sectors related to religious harmony.

This is another task assigned to the district FKUB. It has been carried through media advertising in strategic places, as well as through visual media on TVRI Central Kalimantan which is scheduled regularly. On March 11, 2015 FKUB attended a meeting between religious figures in the Jaya Tinggang hall. On July 15, 2015, a dialogue on religious harmony on TVRI Central Kalimantan was broadcasted nationally. FKUB had a year-end dialogue on TVRI Kalteng with the theme Harmonization of Religious People in the City of Palangka Raya. Evaluation for this task involves phasing and continuity of implementation, mapping of targets, success measures, and materials and methods of dissemination.

e. Providing recommendation on religious facilities construction.

FKUB often received requests to provide recommendations for the establishment of religious building facilities, and after receiving a letter the administrator will usually pay a 
visit to inquire the requirements. If all requirements are met, FKUB administrators will immediately provide recommendations, and even though the most of the administrator are Muslim, they strongly supported the provision of recommendations for the establishment of places of worship for other religions as long as they had fulfilled the requirements. As follows that it is very important to develop religious harmony by not only avoiding prejudice, but also building a sense of empathy for people of other religions or beliefs. For this reason, inter-religious forums also need to be more community-based [13]. The management of the Palangka Raya FKUB has never found major obstacles in providing recommendations. Evaluations on this task involves inventory of the number of requests submitted each year and approvals, verification of whether the recommendations have been made properly according to the Joint Ministerial, FKUB decision meeting, and making sure that the decision was not taken by voting, as well as checking whether a visit was paid before approval was given to make sure that approval was given upon completion of all. The role of the FKUB in Palangka Raya City in accommodating the aspirations of religious and community organizations can be assumed to have been carried out as well, but it is rather difficult to record and evaluate. However as FKUB members represent various religious assemblies, most aspirations can be considered to have been accommodated by the FKUB. Some recommendations from religious and community organizations, such as: FKUB to visit the government to ask their permit for the use of private houses, buildings, hotels as temporary places of worship by issuing temporary licenses. Other alternative is to issue a two-year permit on the use of non-religious building for religious activities purposes. Several other recommendations were to have a 'harmony village' in each sub-district. The establishment of this village was based on the consideration that the village represents all elements of religion recognized in Indonesia. To strengthen the formation of harmony villages, it is necessary to stipulate in a Decree (SK) issued by the FKUB. There are several villages that are considered to represent the picture of religious harmony in the City of Palangka Raya, such as: Pahandut Seberang Village, Tangkiling Village, KM Village. 45 Pager, KM Village. 10 Petuk Katimpun and Desa Kalampangan. But FKUB considered that implementation of these aspirations is not possible at the moment given that the technical instruction for such measure is does not exist. In addition to the five main tasks above, the provincial and city FKUB also have at least three other strategic tasks:

1) Early detection and mapping on religious harmony disturbances

FKUB is expected to be able to identify potential disturbances of religious harmony early by mapping out the harmony as it occurs in the area and by identifying possible effects should the disturbances happen in other regions on the area, and identifying the influence of non-religious, political, economic, ethnic, regional factors, and others that may affect the religious harmony.

2) To mitigate and seek solution to the disturbances

If the state of religious harmony is disturbed, however small the disturbance is, FKUB should be able to help local governments to deal with the disturbance so as not to spread and expand, to reduce it so that the intensity decreases and to find short-term and long- term solutions through negotiations, mediation, arbitration and if adjudication if necessary.

3) To identify and revitalize the local wisdom to support religious harmony Every region has its own local wisdom, both the old and new ones, both directly and indirectly affect religious harmony. Some of the local wisdom is running and functioning properly, but some others are not functioning anymore because they are unable to sustain due increasingly diverse population and the global 
information and communication technology development, so that it needs to be revitalized properly. FKUB tries to design, schedule and carry out socialization of legislation and policies in the religious field related to religious harmony.

In regions where the population is homogenous in ethnicity, culture and religion, people can easily live harmoniously alongside each other. However, changes in social life due to the rapid modernization as well as the increasing number of migrated people have subsequently changed social lives, communities are less homogenous. Many developing regions are now are inhabited by more heterogeneous population.

Collaborative works between different religious groups is possible as long as the members are willing to adhere to their religious doctrines and values, especially ones that are universally taught in every religion such as compassion, respectful relationship, togetherness and the sense supporting others welfare as equal human beings. Other than that, Sari in her research found that FKUB management performs some form communication form such as group communication, held in various forms such as discussion, by conducting trainings and seminars by inviting interfaith leaders who aim to create harmony of religious people and to prevent religious conflicts in Labuhanbatu Distric [14].

Indeed, religion has a strong drive for human beings. Quoting one of Durkein's statements, Koentjaraningrat mentioned the four basic elements of religion, namely religious emotion, belief system, religious ceremonies system and religious community. Religious emotion or the soul vibration causing human to perform religious behaviors; Belief system is the human visualizations to define nature of God; Religious ceremonies system aims to connect with the invisible world based on the belief system; while religious community conceptualizes and activates religion and its religious ceremony system [15].

To understand the meaning of culture in a simple way, Koentjaraningrat quoted Taylor to define culture as that complex whole which includes knowledge, belief, art, morals, law, customs, and many other capabilities and habits acquired by members of society. Koentjaraningrat further elaborated that culture means the entire structure of ideas, action and attainments of human beings in their nature as social creatures which they adopt through learning in life [16]. Based on these definitions, it can be concluded that culture encompasses the structure of ideas that persuade the abstract level of knowledge in the way of thinking within human beings. It manifests through behavior and concrete, man-made creation of social tools such as behavior, language, life tools, social organization, religion, arts, etc, all of which is meant to facilitate human beings in living their lives. In the real world of social life, cultural and religious values drive the individual behaviors by which communities lead their social life. Such cultural and religious values play important roles in building harmonious live among religious groups. The core value of collaboration among religious people is to establish a collective standard of living that would support each other in fulfilling needs in life. Therefore, building collaborative works of life among religious communities can be applied across different aspects of social life, including economic, social political, cultural and security aspects. In other word, if the government expects to have all elements of its community to work together collaboratively, it is imperative to be attentive of and to respect the aspiration from religious groups as they aim for justice, welfare, righteousness, morality and equality to be applied in the nation and the world as a hole, to realize a united and advance government. Meanwhile, FKUB Pekalongan City as one of the organizations that can be a peace spreader among young people, women, and the smallest structure of the State, the family. Religious harmony is an important part of creating dialogue, understanding of Pancasila and being united in diversity [17]. It is therefore imperative for the people in Indonesia to continuously create conducive environments 
for and to maintain the harmony among religious groups. At the same time, we have to look closely at the local values that support the collaborative, religious and cultural values that are important for religious groups' harmony.

\section{b) Fostering Mutual Respect Among Religious People}

Local Wisdom comprises two important words of its own: 'local' and 'wisdom'. The word local refers to a particular area or neighborhood, while wisdom refers to the quality of having good judgment or being wise. In general, local wisdom is defined as the collective ideas that are embedded in and adhered to by specific group of people in particular area that was derived from good judgments, knowledge and good values specific to the locals [18].

Local wisdom can be considered as the explicit knowledge built from a long period of evolution in a community and its environment, within collective local system. Substantially, local wisdom is the prevailing values in a particular community. These values is believed and referred to by the members of the community. Therefore, it can be said that local wisdom is an important entity that define the pride and dignity of the community living by it. This means that elements of local wisdom that reflects the local creativity and knowledge of the elites and community would define their civilization.

To sum up, local wisdom encompasses the entire aspects of community life, particularly those related to social rules for interaction and relationship among people, between people and environment, and between people and spiritual entities. There are at least six significances and function of local wisdom as it is being utilized as a social tool to support religious harmonies: first, it serves as the identity of a community; secondly, it serves as social adhesives to the community; thirdly, as opposed being imposed top-down, it comes from the existing cultural elements that are created bottom-up; fourthly, local wisdom adds color to the harmony living of community; sixth, the local wisdom could serve to encourage sense of togetherness, appreciation and the mechanism that could possibly brush aside threats of reducing and damaging the sense of communal solidarity as it is built on collective awareness in an integrated community.

Meanwhile, in Malaysia, the outcome of the study as similar through the development of a socio-religious harmony development model not only proposed 23 socio-religious harmony factors to promote and develop harmony among multi-religious adherents in Malaysia but more importantly proposed how these factors connected with each other to render a holistic view on factors to build a sustainable harmony society. Through the output of the model, the experts viewed that certain factors need to be addressed simultaneously rather than in isolation in dealing with a complex situation like socioreligious harmony [19].

For that reason, culture and religion at a certain level has similarities in terms of the influence it has to drive human life. Both of them have a value system to which the followers adhere, although they are of different origin. The submission to the actualization of values from both religion and culture in community is so strong that it has implication to the human personality who practices it. Consequently, it is logical when responding to a religious or cultural sentiment, people would react emotionally and group solidarity may rise more likely than when they are responding to other aspects. Accordingly, religion can be said to retain potential conflict as it also retains potential integration. The matter lies on how the different religious groups can build a good, harmonious relationship that build mutual strength within each group and eventually creating conducive environment for a harmonious, united and solid community, inline with the nation's slogan, Bhineka Tunggal Ika.

To Indonesian citizen, the concept of harmonious life is not something new or difficult to 
realize. It is an understanding that has been inherited from the ancestors long ago, which goes all the way back to the Majapahit and Mataram Kingdom era. Today, harmonious life is even formulated in the country's law, UUD 1945, specifically in verses under article 9 of the law, in which the freedom to practice religion is protected. In addition, it is also written in the TAP MPR II/1978: document of P4 on the exposition of the first verse of Pancasila, keTuhanan Yang maha Esa; and further reflected through the slogan of Indonesia, "Bhineka Tunggal Ika" which literally means unity in diversity. Religious harmony is not merely an empty discourse for the country; in fact, it has been instilled into the characteristic of the nation, reflected through the day-to-day relationship among the people, and practiced across the communities in Indonesia. To the Christian community in particular, to life a harmonious life is the call of faith. Yewangoe, quoting Eka Darmaputra, mentioned to his reader to always be reminded that the concept of harmonious life should not be underrated or viewed as merely an obligation. He believes that harmonious life takes efforts to make it happen [2]:

a) An authentic and dynamic harmony. By authentic, it means that the harmony is a reflection of the sincere and pure intention of the people, and dynamic mens that the harmonious relationship is not limited to simply living co-existently alongside each other. A dynamic harmony means that members of different religious groups continuously working through a dynamic, proactive and creative efforts to achieve high-quality, mutual agreement in their relationship. It is based on the biblical foundation that God has entrusted human to work on the garden to dress it and keep it (Genesis 2:15).

b) Harmony and freedom, simply means that there is balance in harmony and freedom of community in building social relationship. This implies that the harmony should be reflected in the freedom of relationship itself as opposed to restrict or put it off. Only from the true freedom of relationship the harmonious relationship would be born. The meaning of freedom in Christianity is the state of liberty that is inseparable from obedience and vice versa, where obedience comes from a free will without any coercion from any sources whatsoever. The combination of these two makes a stateof responsibility. Jesus Christ had set an example of this when He was in the peak of His misery. When completing the work of salvation, the Lord Jesus had the absolute freedom of choice, yet He opt for obedience. Therefore, the freedom of religion is not an excuse to allow the followers to do anything without purpose. The freedom of religion should be taken in a responsible manner. One of the examples of such responsibility is to take part in the efforts of maintaining mutual welfare of the community. To take any action in the name of freedom does not reflect Christian attitude at all. Religious freedom is one of the most important elements in Human Rights. The ability of human beings to lead a religious life is a privilege from God. God has never coerced human to obey or not obey. In the light of this understanding, the freedom to embrace our faith should be cherished as we are not only demand for human rights, but also to take on what has been granted to us as our rights from the Almighty God.

One of the supporting factors in maintains religious harmony for FKUB is the knowledge that religions are now developing in Palangka Raya. Many people migrating to the city over various reasons: trading, spiritual, and religious activities. There has never been religious conflict in Palangka Raya so far. This historical reality reinforces the opinion that the nature of the religion doctrine in Palangka Raya is in keeping with the religious harmony spirit. The Dayak's Huma Betang Philosophy of the Central Kalimantan Dayak community allows spaces 
and freedom for all religions to develop and carry out their roles in among the society.

Huma Betang is a typical home of Dayak people in the past that is large, tall and long, inhabited by many families. A Huma Betang's cultural philosophy in building the life of religious people in the City of Palangka Raya by Dr. Mohammad and Abubakar, H.M, there are several values held by this view:

1) Equality, meaning that Dayak people do not recognize feudalism, instead what applies is the principle of equality, where everyone holds the equal position before Ranying Hatala Langit (the Kaharingan God), men and women have the same responsibilities in the family. In Betang house all residents have the same responsibility and position, and the spirit binds them to be together to maintain peace and tranquility.

2) Brotherhood and kinship, that is, everyone is brothers to the others, therefore all problems in the community are resolved in deliberations to reach consensus in the bond of brotherhood and extended family

3) Belum Bahadat, in Dayak language this literally means living up the customary law and tradition, meaning the basic principles that uphold the values of customs that emphasize value and spiritual as respect for parents, neighbors, the universe and the Creator. The philosophy where the earth is rooted in the sky is upheld is emphasizing the moral attitude to appreciate the culture.

4) Religious relationship, meaning religious differences in Dayak community are not considered crucial, people live in mutual respect and mutual respect in the spirit of brotherhood and kinship. Therefore, if something goes wrong with this general principle, all parties will immediately sit together to find a solution. All parties agreed that no matter how small the religious nuances of the conflict would occur, it must be immediately localized, solved, and extinguished and then everyone start anew again on the foundation of friendship and brotherhood.

As for the inhibiting factor for FKUB Palangka Raya in implementing its function is the management of tasks because most of the committee members are religious leaders and public figures and thus they have to share their responsibilities between the FKUB function and their role in their groups. Many times, scheduling a meeting has been too challenging as it was difficult to have all interested parties present. However, it was very well understood that the function and responsibilities of FKUB requires serious dedication of time and consentration as the matters in hands are the complex multi-religious issues.

\section{Conclusion}

The role of FKUB in setting up dialogues with religious and community leaders has been carried out through formal and non-formal dialogue activities, through meetings with community leaders, religious leaders, and regional governments, the sub-Ministry of Religion of Central Kalimantan, the security forces of the palangkaraya police, the court, the national security unit and the army office. With all related elements engaged, everyone is united and work together for the religious harmony in Palangka Raya. Other than that, the role of FKUB 
in channeling the aspirations was carried out through several accommodating aspirations to control prostitution areas and the establishment of harmony villages. The role FKUB in the dissemination of legislation and policies in was carried out through media broadcasting and publications, and through the installation of billboards on religious harmony and community development. One of the factors supporting the role of FKUB to carry out the task smoothly is the philosophy of Huma betang which allows all religions to develop and practice their culture among the society. As for the constraints, most FKUB administrators are community leaders and too difficult come together for the management meeting.

\section{References}

[1] Paul F. Knitter, (2012), Satu Bumi Banyak Agama. Jakarta: BPK Gunung Mulia

[2] A. A. Yewangoe, (2009), Agama dan Kerukunan. Jakarta: BPK Gunung Mulia

[3] Olaf Herbert Schuman, (2011), Agama-agama dan Kekerasan. Jakarta: BPK Gunung Mulia

[4] Rambe, Toguan. (2019). Kontribusi A. Mukti Ali dalam Kerukunan antarumat Beragama di Indonesia. Journal of Islamic Thought and Muslim Culture (IJITMC), 1(1), 43-60.

[5] Kusnidi, (2010). Peranan FKUB dalam pelaksanaan Pasal 8,9 dan 10 PKMno 9 dan 8 Tahun 2006. Jakarta: Badan Litbang dan Diklat Puslitbang Kehidupan Keagamaan

[6] Utami, Nadia Wasta. (2016). Upaya Komunikasi Forum Kerukunan Umat Beragama (FKUB) dalam Resolusi Konfl ik Ahmadiyah. Jurnal Ilmu Komunikasi, 13(1), 61-72

[7] Yasa, Wayan Sastra, et.al. (2019). Effect of Cultural of Family, Conflict Management, And Tolerance Inter-Religious Harmony Stability of People in Batam. Indonesian Journal of Educational Review, 6 (2), 27-41

[8] Khotimah. (2015). Religious Harmony and Government in Indonesia. Jurnal Ushluhuddin, 23(1), 96-107

[9] Nicolas,J., Wolly,dkk., (2009). Nilai-Nilai Agama Sebagai Motivator Pembangunan, Kupang: Yayasan Penerbit Gita kasih

[10] Firdaus, Anang. (2014). Eksistensi FKUB dalam Memelihara Kerukunan Umat Beragama di Indonesia. Jurnal Kontekstualita, 29 (1), 63-84.

[11] Rokhmad, Abu. (2016). The Role of Inter-Religious Harmony Forum in Maintaining the Harmony of Religious Life in Plural Society. The Social Science Journal, 11 (21), 5052-5059.

[12] Basrowi \& Suwandi, Memahami penelitian Kualitatif. (Jakarta: Rineka Cipta, 2008), 209-210

[13] Latifah, et.al. (2019). Perception of Banyuwangi and Blitar Society on Religious Harmony. Jurnal Pencerahan, 12(1), 36-44.

[14] Sari, Etika dan Elis Mayanti. (2018). Communication Effectiveness of Religious Harmony Forum (FKUB) in Preventing Religious Conflict in Labuhanbatu District. Jurnal Bimas Islam. 2 (2), 325364

[15] Koentjaraningrat, (1978). Kebudayaan, Mentalitet dan Pembangunan, Jakarta: Gramedia

[16] Koentjaraningrat, (1990). Pengantar Ilmu Antropologi. Jakarta: Rineka Cipta

[17] Adzim, Abdul. (2019). Religious Harmonization as Deradicalisation Efforts Through Interfaith Communities - A Case Study of the Religious Communication Forum (FKUB) in Pekalongan City. Islamic Studies Journal for Social Transformation, 3(1), 21-36.

[18] Ridwan, Nurma Ali. (2007). Landasan keilmuan kearifan Lokal. Jurnal Studi Islam dan Budaya Lokal. Jurnal P3M STAIN, 1(1), 27-38

[19] Abdullah, M. Riduan Tony Lim, et.al (2017). Sustainable Socio-Religious Harmony Development 
In Malaysia: An Interpretive Structural Modelling For Multi-Religious Society. Jurnal AlTamaddun Bil, 12(1), 53-64. 